\title{
cinchophenによるペプシン分泌に関する 犬の胃腺主細胞の電子顕微鏡的研究
}

\author{
牛尾彰 \\ 群馬大学医学部第一外科学教室 (主任 石原恵三教捜)
}

cinchophenは古くから抗りウマチ椤として 使用さ れているか，1931年にChurchill and Van Wagonerか 犬に打いて胃僓瘍の発生を報告してから，比類まれな る実験的慢性潰瘍をつくる有力な手段として広く知ら れている。しかし，その成因についてはいまた十分に 解明されていない. cinchophen による胃液分佖作用 はさほと強いものてなく，粘液とくにノアル酸の分佖 か有意な減少を示し6)，胃粘膜に対しては酸ペプンノ の侵罀作用よりもむしろ粘液による防禦作用の減退か 注目される。教室の研究によると，cinchophenによる 胃液分北ては酸度の上昇は軽度てあるか，ペプシンの 分必加著明て, 6 時間を頂点とする遅発的上昇か特徴 的てある。その分必曲線はインンュリンと異なって $\mathrm{A}$ C THのそれと一致する。そして cinchophen による 胃液分必か下垂体茎分断または副腎剔除により抑制さ れ，迷走神経切断によっては阻止されないことから も，下垂体副腎皮質系を介する液性機序の存在か知わ れる122)314)。これらの論抛をなす教室の実験テーター は, 胃液の生化学的研究と胃腺の光学顕微鏡的研究に よってえられたものてあるか, 私は電子顕微镜を用い て胃腺主細胞の超微横造の変化を追究し, 作用機序に ついて三三の知見を得たのてその結果を報告する。

\section{I 実験材籵と方法}

実験動物には体重およそ8 kgの雄性雑種成大を使用 し，食慨として dog foodを1日1回与えた。実験は 正席大のほかに下垂体茎分断大及ひ迷走神経切断大を 用いて24時間絶食後に cinchophen $90.15 \mathrm{~g} / \mathrm{kg}$ を経口 投与し，4時間後に胃腺主細胞の変化を観察した. ま たインノュリノ2 I U / kgの静脈内注射後 1 時間の胃腺 主細胞の変化を調へてこれとも比較検討した。各実験 例は 2 匹を 1 群とし, 各々の所見か相違する場合には さらに追加して調へた. 動物をラホナールて麻酔した 後, 開腹して胃体部大弯側の一定部位から約 $5 \mathrm{mmcu}$ の組織片を採取し, 直ちに cacodylate bufferにより PH7.4に調整した $5 \%$ Glutaraldehyde 溶液を盛った
時計皿中て細切し約 $1 \mathrm{~mm}^{2}$ の大きさとなし，さらにこ れを同し固定夜を入れた瓶中て $0^{\circ} \mathbf{C}$ 約 2 時間半固定し た. 固定後組織片は cacodylate buffer て約 1 時間洗 策した後, caulf 1eld氏 $1 \% 0 \mathrm{sO}_{4}$ 容液を大れた瓶中てO。C 約 1 時間半後固定した。次いて漸強エタノール系列に て型の如く脱水後Epon に包埋し，L E I T Z社製超 ミクロトームて薄切し，醋酸ウラニウム，水酸化鉛て 2 重杂色し，J EM一 5 型または J EMー7 型電子顕 微鏡て観察した．両側迷走神経の切断は横隔膜下にて 行い，術後 2 週間て実験を行った，下垂体茥分断は口 蓋経由て行い, 術後2週間て実験を行った。

\section{II 実 験 成 績}

\section{A 正常犬（無処置犬）における実験}

1 飢餓時の胃腺主細胞所見

細胞はやや広い基底部をもつ円錐形て，飢餓状態て は多量の分修顆粒をもち，ほほ円形乃至棈円形の核か 基底側に偏在し，通席 1 2 個の大きい核小体かあ る.図1の示すように，核側部から腺腔面に至る細胞 質の大部分は分班顆粒によって充たされる，分必顆粒 (チモケノ顆粒) は一般に電子密度か低く，限界膜て つつまれ, 内部に中等度乃至低電子密度の均質性内容 を入れる，分北顆粒の融会も㕍々見出される．腺腔面 に於ける分必顆粒の排出像は少い.Golg1装置は核上部 にあるか，分必顆粒の間の狭い部分に分散して見え る. Golg1 層板の拡大およひ分必顆粒形成像は著明て ない. 粗面小胞体は層板状に配列している。糸粒体は 細胞側壁抢よひ核側部から核下部に見られ，限界膜お よひ糸粒体稜はかなり多く, 横に密に配列する, lysosome は大小球形高電子密度の小体てその数は少い。 腺腔面には少数の短い microvill1 かある。隣接細胞と 接する細胞側面の腺腔端にはJunctional complex（閉 鎖是）かみられ，深部には細胞間嵌合かある．基底面 の形質膜に侣って基底膜かある。

2 インンュリル投与後の所見

核上部から細胞先端部にみられる分必顆䊀は非常に 
減少し, 腺腔面に於汀る分必顆粒の排出像は多く, 分 必物の拂活の増加か明らかてある。Golg1 装置は核上 部にまとまってょく発幸し, Golg1 層板の拡大ならひ に分必顆粒形成像か著明てある。粗面小胞体は㩔平囊 の内腔の病大により多数の不規則形囊か現われ，やや 密度の高い内容を入れ，層板構造か殆九之悄失してい る。この変化はお抢らく粗面小胞体か旺盛な分必顆粒 形成に関与するためてあろう。細胞間嵌合糸粒体には 特記すへき所見はない. lysosomeは明らかに増加し， Golg1 装置の周囲或は内部に多い，以上の所見より胃 腺主細胞はイノノュリノ投与により強く分必を刺㦸さ れることか観察された。

3 cinchophen 投与後の所見

核上部から細胞先端部の分脩顆粒は減少し，腺腔面 に於ける分必顆粒の排出像か多い。しかしイノノュリ 一投与例に比へ分必顆粒の減少の程度は弱い。図 2 の 示すように，Golg1 装置は核上部にまとまって見出さ れ，分必顆粒の形成は旺盛てある。すなわち, Golg1風 板の拡大か著明て多数のGolg1空胞か現われ，Golg1野 の内部或は周囲には小さく不規則形の若、分必顆粒か 多く見られる。粗面小胞体は細胞基底部之核側部に鲞 板状に配列し，扇平囊か空胞状に拡大した部分も見ら れる。これは洔に Golg1 䒾置の近くに見えることかあ るか，西まり著明てはない，しかしイノノュリノ投与例

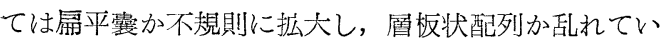
るのて所見の差かみとめられる.糸粒体はGolg1野の周 团, 細胞基底部, 細胞則壁に主としてみとめられる。 Iysosomeは少いか Golg1 野周扨にみられる。細胞側面 形質膜に見られる可なり複雑な細胞間岸合には変化な く, 又腺腔面の microvillı は智かく少い, 以上の所見 より胃腺主細胞は cinchophen 投与により強く分必を 刺㦸されることか観察された。

\section{B 下垂体茎分断犬における実験}

1 飢餓時の所見

正席犬に比へて細胞の大きさか明らかに小さくなっ ている。核およひ㤥小体には特に変化はみとめられな い.図了の示すように，分偊顆粒は核上部から細胞先 端部まて充満してみられるが, 排出像は始んと見られ ない.Golg1 装置は核上部て分必顆粒の間に見られる か，Golg1層板或はGolg1空胞の拡大は著明てなく，分 佖顆粒形成像も著明てはない，Golg1 小胞はあまり減 少していない，粗面小胞体は著明に減少し層板状配列 は蹯となり涮平囊の間隔か広くなっている，糸粒体は
細胞側壁抢よひ核側部から㤥下部にみとめられる。大 きさ，数及ひ糸粒体稜の変化は明らかてない，以上の 所見から，胃腺主細胞は茎分断により細胞の萎縮，と くに粗面小胞体の減少することか認められた。

\section{2 イノノュリノ投与後の所見}

四4 の示すように，核上部から細胞先端部には分必 顆粒かかなり多い，腺腔面には分生顆粒排出像か見ら れる。核上部て分北顆粒の間に Golg1 装置か見られ， Golg1 首板の拡大ならひに，分必顆粒の形成像か著明 てある. 粗面小胞体は, 茎分断大の飢餓分必像に比一 てやや増加するか，扇平囊に拡大部かあらわれ不規則 囊状のものか多く, 首板状の配列は乱れている. 図 4 に見られる分必顆粒間の小空胞は限界膜にribosomeか 附着しており拡大した粗面小胞体霊てある。糸粒体， microvilli, 細胞閜嵌合には著変はない. lysosome は 主に Golg1 野周囲にみとめられるかそれ程増加してい ない. 以上の所見から胃腺主細胞は細胞の菱縮, とく に粗面小胞佮の減少かあるにもかかわらす，強く分必 を刺㦸され，とくに粗面小胞体か著明に刺㦸されるこ とか認められた。

3 cinchophen投与後の所見

図 5 の示すように，分偊顆粒は核上部から細胞先端 部を充たし，減少もなく，又排出像も殆んとない。 Golg1 䒾置の層板の拡大山殆ん之みられす，分必顆粒 形成像も飢餓の場合と同嵄極めて弱い，たた細胞先端 部の分北顆柆間にはかなり多くの小空胞か認められ る. 柤面小胞体の減少は下垂体茎分断大の飢餓分化像

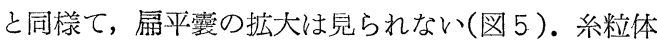
microvill 1 等の所見も同様てある。このように茎分断 犬の飢餓分必像に此一，細胞先端部の小空胞に多少の 変化かみとめられるか，その他の所見については変化 はみとめられない.イノノュリノ投与例とのちかい は, Golg1 層板の拡大およひ分必顆粒の形成像かほ之 んとみられないことと, 粗面小胞体の変化かみられな いことてある. 以上の所見から下垂体茥分断を行うと 胃湶主細胞は cinchophen を投与しても分修を殆んと 刺㦸されないことか認められた。

\section{C 迷走神経切断大における実験}

1 飢餓封の所見

正席大に比へて核抢よひ核小体には持に変化はみ上 められない，図6の示すように，核上部から細胞先端 部に分必顆粒か充藏し，核側部から基底部にまて。お よふものかある。分必顆粒の排出像は殆んとない。 
Colg1凩板およひGolg1 空胞の桩大は始んとみられす, しかもGolg1小胞は少なく，Golg1野に於ける分必顆粒 の非成像も少い. 俎面小胞体は比較的少く層板状に配 列している．糸粒体は細胞側壁打よひ核側部から核下 部にみとめられる. lysosomeはみとめられるか非席に 少い. 腺腔面の microvillı は短くて少く, 細胞間嵌合 には変化はない，以上の所見から，Golg1 小胞の減少 粗面小胞体の軽度減少がとめられる以外には, 正常 犬飢餓分偊像とほとんと差がな、このことから胃腺 主細胞は迷走神経を切断しても下垂体茥分断のように 強い変化をおこさないことか認められた。

\section{2 イノンュリノ投与後の所見}

核上部から細胞先端部には分必顆粒か充珮し，分佖 顆粒排出像は少い. Golg1 䒾置は分化顆粒間にあり, Golg1 層板の脏大は著明てなく, 分必顆粒の形成像も 多くはない。細跑基氐部から核側部にかけて粗面小胞

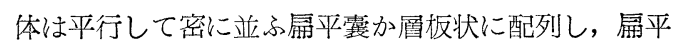
囊の拡大は認められない. 糸粒体腺腔面のmicrovill1, 細胞間嵌合等の所見は迷走神経切断大の飢餓分化例々 同様てある.以上の沂見から，迷走神経を切断した犬 の胃腺主細胞はインンェリンを投与しても分必を殆ん と刺㦸されないことか認められた。

3 cinchophen投与後の所見

図7の示すように，分佖顆粒は核上部から細胞先端 部にかなり多いか，図８の示すように，分佖顆粒の排 出像もかなり認められる。Golg1 装置は核上部て分佖 顆粒間にあり，Golg1 層板の拡大は著明てはないか， 分必顆柆の形成像が琹められる（図７）．粗面小胞体 糸粒体, 腺腔面の microvillı, 細胞間嵌合等について は迷走神経切断犬の飢餓分必像と同樣てある.イノノ エリン投与例とのちかいは，分必顆位の排出像かかな りみとめられることてある. 以上の所見から迷走神経 切断犬の胃腺主細胞は cinchophen を投与するとなお 分必像かみられ，イノノュリンのように強い抑制をう けないことか認斿られた。

\section{正考按}

胃沝の超微構造については1951年D A L T ON(7)か 発表して以来数々の報告かあるか, 胃腺主細胞につい て最近，柴崎等(8)か冬眠キクカンラコウモりを使って 詳しく報告している，胃腺主細胞なとの蛋白分必腚に おいては，分必物の合呅注粗面小胞伶て行われ，公必 物の農縮による分必顆粒の形成は Golg1 装置て行われ
ることか分っている(5)，糸粒体は酸化酵素系を含みこ れによってエ不ルキーの供給者の役割を果し, lysosomeは酸性フォスファターセその他の”水解酵素を含み 細胞内て蛋白合成か行われている時に有効に㗢くもの と考えられる.このように Golg1 䒾置との他の細胞内 小器官は分必過程てそれそれの役割を果しているの て，その㗢き具合に応した形態的変化を示すことか考 えられる。柴猗(9)はラ，トて，HE L A N D E R(10)か マウスて給食後の変化を観察している。これらによる と飢餓時には Golg1 譄板の拡大はみられす, 分必顆粒 の帅成像も多くはない. 粗面小胞体は層板状に配列し ている。糸粒体は細胞側壁およひ核側部から核下部に みとめられる。給食後ては Colg1 層板の拡大か著明て あり, Golg1 小胞も増加し, 分化顆粒の形成像か 著明 てある. 粗面小胞体は内腔か拡大し不規則囊状のもの か多く層板構造を呈するものはみられない. 系粒体は 主に Golg1 野に接してみとめられる。

本実䂆ては，犬に cinchophen を投与し，またイノ ンュリノを投与して比較観察した。分必顆粒の減少， 著明な分必顆粒排出像, Golg1層板の拡大, Golg1小胞 の増加, 著明な分䛑顆粒形成像, 粗面小胞体の扁平霡 の不規則な拡大による層板状配列の乱れ等の形態学的 に分北を刺韩された所見は両者てみとめられた（図 2) ・しかし cinchophen 投与例てはインンュリン投 与例之違って, 分必顆粒の減少の程度か弱く, 粗面小 胞体の層板状構造の乱れはなく, lysosome はより少 い.これらの点から, cinchophen はイノシュリンに 比へて代謝亢進度のいっそう弱いことか推則される。

長冯(4)は光学顕微鏡的に下垂体茎分断犬の胃腺主細 胞て分佖空胞か胞体に充䓢していて，イノノュリン投 与後には正常犬と同様の分化周期をみたか, cinchophen 投与後には分化像になんらの動きもみられない と報告している. 本研究の電子顕微鏡像ても下垂体茥 分断犬の飢餓時には分必顆粒か核上部から細胞先端部 まて充蒠しているのかみられた。 Golg1 層板の拡大お よひ分修顆粒の形成像は著明てない.とくに本研究で えられた持長的な所見は正常犬に比へ粗面小胞体か著

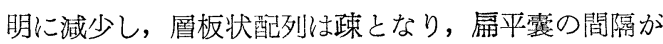
広くなっていることてある(四了）．インンュリノ投与 後には，Golg1 層板の抾大およひ分必顆粒の形成像か 著㫜て, 粗面小胞体はやや増加し, 不規則囊状のもの か多く，層板状餗列は乱れている(図 4 ). cinchophen 投与徢ては，細胞先端部の分必顆粒間の小空胞に多少 
の変化がみとめられるが，その他の所見については変 化がみとめられない（図５）．以上のことから，イン シュリンは茎分断犬においても著明な分泌機能充進像 をあらわすが, cinchophen のペプシン分泌效果は下 垂体茎分断によって阻止されることが認められた.

長沢(4)は迷切後の飢餓分泌像では R N A に乏しく空 胞が多く，インシュリン投与後にも空胞がいつまでも 胞体内にたまって排泄されないが, cinchophen 投与 後には正常大でみられたと同様の分泌循環像が出ると 報告している. 本研究の電子顕微鏡像でも迷走神経切 断犬の䬣餓時では, 分泌顆粒は胞体内に充满してい て, 分沁顆粒排出像は殆んぞみられない（図6）。

Golgi 嘚板の拡大おょび分泌顆粒の形成像は少い。ま た粗面小胞体がやや減少していることは, 長沢の記載 しているR N A 減少と一致する. 迷切犬のインシュ リン投与年後では飢餓時に比べほとんど変化がみとめら れない. cinchophen 投与では分泌顆粒の排出像がか なりみとめられるが, Golgi 層板の拡大および分泌顆 粒の形成像は著明でない（図 7，8).この所見は長 沢の正席犬でみられたと同様の分泌循環像があるとい う記載とはやや異なり，分泌がかなり抑制されている ことをあらわしている。これにより，迷走神経切断に よりインシュリンのペプシン分泌効果はほとんど完全 に抑制されるが, [cinchophen のペプシン分泌効果も かなり抑制されることがみとめられた，上記の諸所見 から cinchophenは胃腺主細胞の分泌を克進させ, こ の效果に下垂体茎分断により強く阻止され, 迷走神経 切断によっても正常犬に比へてかなり抑制されること が知られた。

\section{IV 総括}

cinchophen による犬の 胃腺主細胞の電子顕微鏡的 変化をインシュリンのそれと比較検討した。

正常犬に cinchophen を投与すると, 分泌顆粒が減 少し, 腺腔面における分泌顆粒の排出像が増加し, Golgi層板の拡大および分泌顆粒形成像が著明となる. 粗面小胞体は, インシュリンでは層板状配列を乱して
いるが， cinchophen ではこれと違って層板状に配列 している。

あらかじめ下垂体荃を分断した犬に cinchophen を 投与すると，分泌顆粒が多くみられ，腺腔面における 分泌顆粒の排出像が殆んぞなく, Golgi 㬝板の拡大も 殆んぞなく, 分泌顆粒形成像が䄈めて弱く, 粗面小胞 体が層板状に疎に配列していて，インシュリンで見る ような分泌充進像が見られない。

あらかじめ両側迷走神経を切断した犬にcinchophen を投与すると, 分泌顆粒が多くみられ, 分泌顆粒の排 出像もインシュリンと異なってかなり見出され, Golgi 層板の拡大および分泌顆粒形成像が著明ではない がみられ，粗面小胞体が層板状に配列している。

以上の所見より cinchophen は胃腺主細胞の分泌を 兄進させ，この効果は下垂体茎分断により強く阻止さ れ, 迷走神経切断によってもかなり抑制されることが 知られた。

稿を終る汇臨み, 御愍篤なる御指導御校閲をいただいた石 原教授に表心より感謝の意を表すると共に, 形態学的所見お よび検䥞資料作製て䦕して御教示御協力它いただいた解部学 伊東教授ならびに柴崎助教授に深謝し, 本研究に御協力下さ った本教室ならびに解剖学教室員各位に感锹致します。

\section{文献}

1) Ishihara, K.\&I. Ishizaka : Gunma J.Med.Sci., $7: 59,1958$.

2) 石坂一郎: 北関東医学, $10: 317,1960$.

3) Ishihara, K., J. Kawafuchi, K. Kano \& I.1shizaka, :Okajimas Fol. Anat. Jap., 28:477, 1956.

4) 長沢久: 北関東医学, $10: 339,1960$.

5) 黒住一昌: 臨床科学, $1: 284,1965$.

6) 中村茂 : 北関東医学, $19: 105,1969$.

7) Dalton : A.J.Am.J.Anat., $89:$ 109, 1951.

8) Shibasaki, S., K. Kobayashi \&Y. Umahara : Archivum Histol. Jap., 26 : 389, 1966.

9 ) 柴崎晋: 日本組織学記録, $21: 251,1961$.

10) Helander, H.F. : J.Ultrast. Res., 10:160, 1964. 


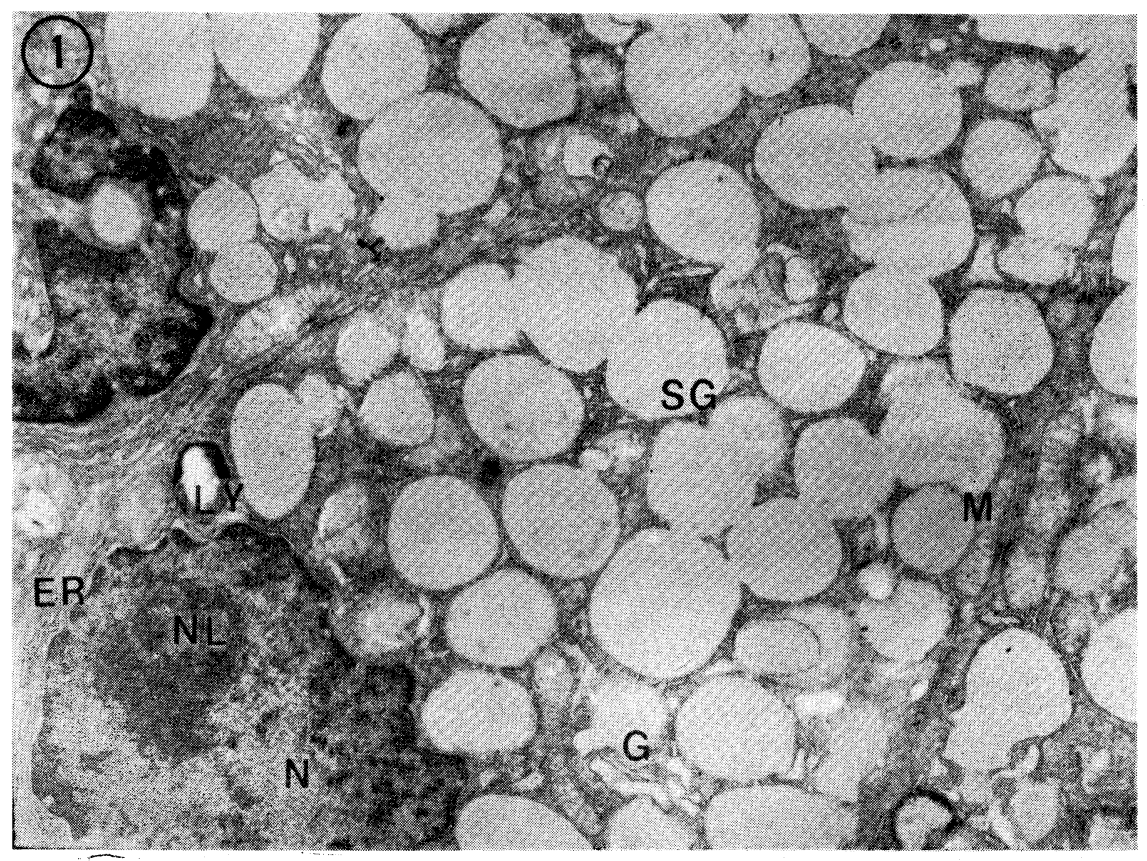

図 1.正常犬（無処置犬）の飢餓時胃腺主細胞。

細胞はほほ円錐形で，核(N)は基底側に偏在し核小体（N L) をもつ。核側部から腺腔面にかけて多数の中等度電子密度 の分泌顆粒 ( $\mathrm{S} \mathrm{G}$ ) がある。Golgi 装置(G)は分泌顆粒の間に見られる。Golgi 層板の拡大, 分泌顆粒形成像は著明でな い。禾粒体(M)は細胞側壁と核周囲に見られ，粗面小胞体（E R ）は層板状で，lysosome（LY）は少い。 $\times 6,100$

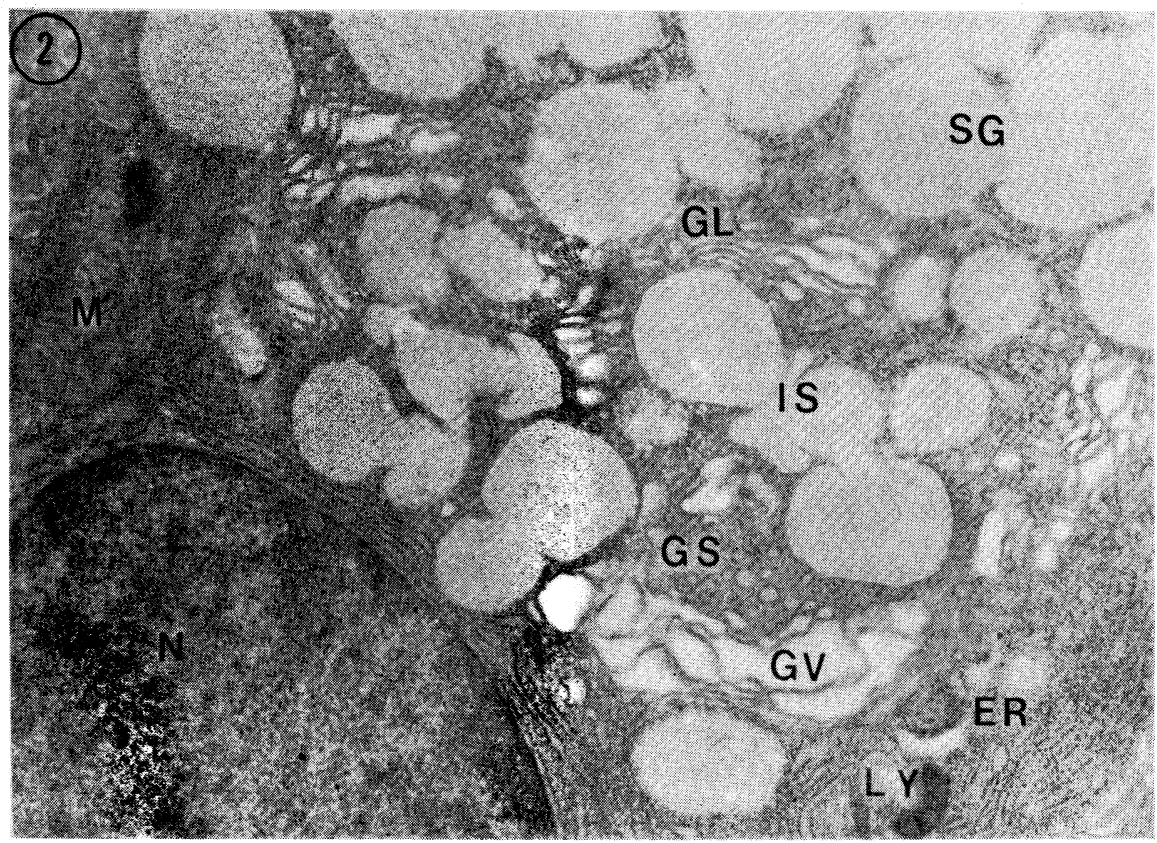

図 2. 正常犬のcinchophen 投与後胃腺主細胞。

分泌顆粒（S G) は隇少し，分泌顆粒形成像は著明である。Golgi 層板 (GL)の拢大によるGolgi 空胞 (GV)の出現 Golgi 小胞 (G S ) の增加が見られ, Golgi 装置の周囲には不規則形の若い分泌顆粒 (I S) が多く見られる。粗面小胞 体 (ER) は層板状で; 釆粒体(M)もみとめられる。lysosome (LY) は少い。 X10,300 
(100)

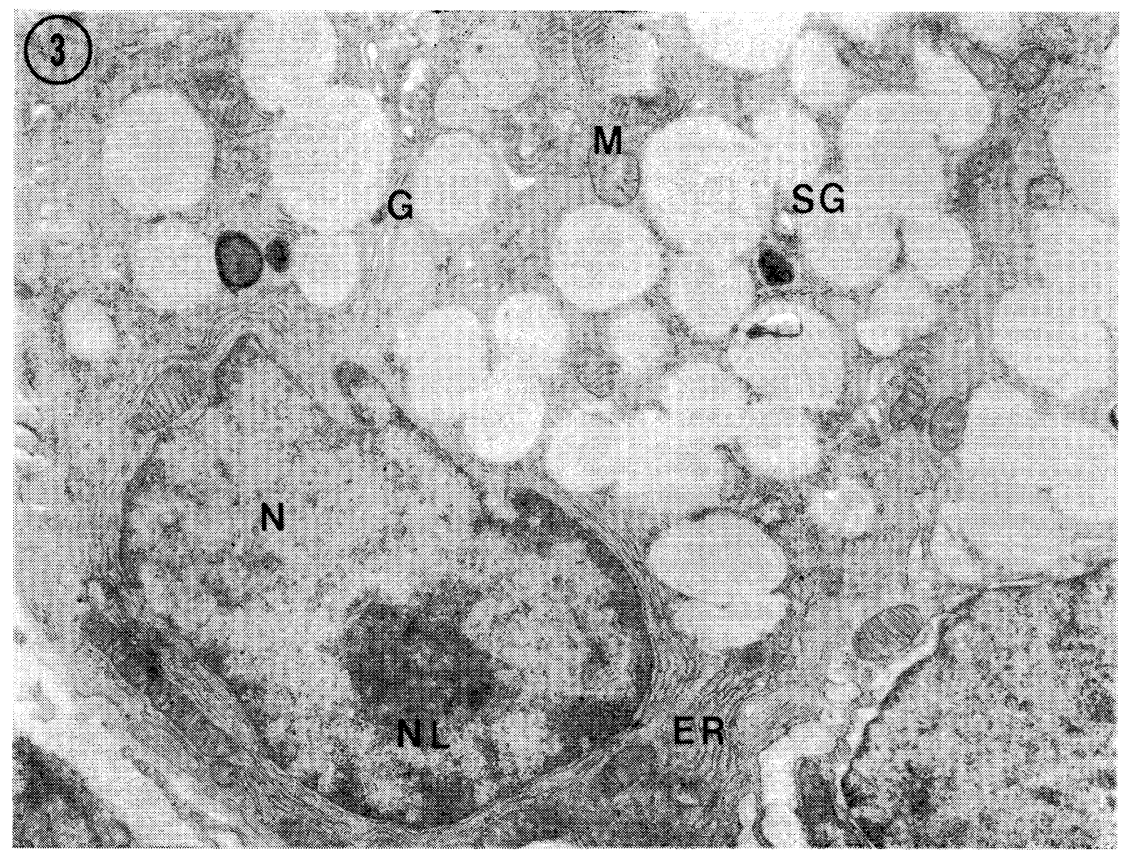

·図3.下垂体荎分断犬の飢諓時胃腺主細胞。

分泌顆粒 $(S \mathrm{G})$ は核上部に充満している。Golgi 装置(G)は分泌顆粒の間にみられ、Golgi 層板の拢大は著明でなく, 分泌顆粒形成像も著明でない。粗面小胞体 (E R ) は著明に減少し, 層板状配列は踈である。系粒体( 核周囲にみとめられる。 $\times 8,500$

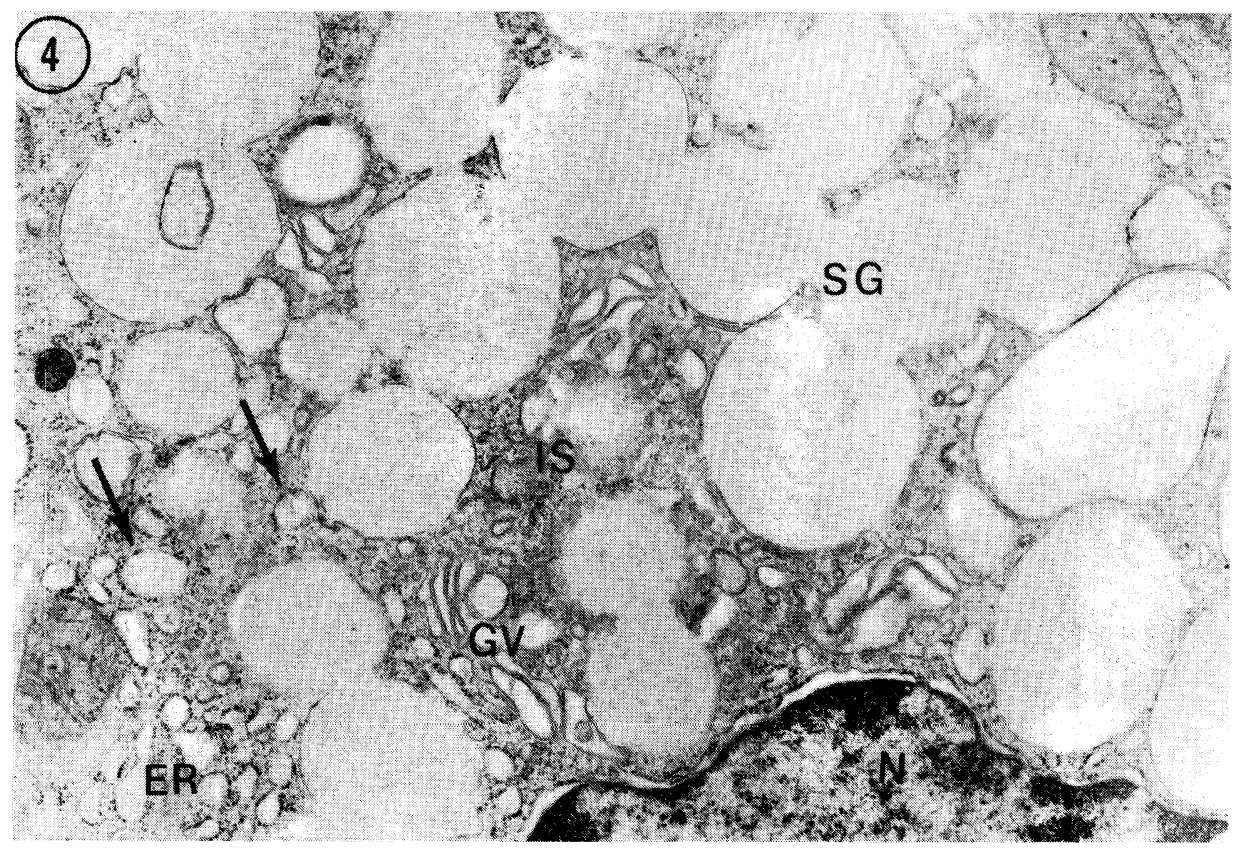

図 4.下垂体蓄分断犬のインシュリン投与後胃腺主細胞。

分泌顆粒 $(\mathrm{S} G)$ はかなり多く，その間にGolgi 装置(G)がある。Golgi 空胞 $(\mathrm{G} \mathrm{V})$ が多数みられ，分泌颗料形成像は 著明である。不規則形の若い分泌顆粒 (I S ) がみられる。粗面小胞体 (ER) は空胞状のものが多く, 層板状配列はみ られない。分泌顆粒の間にある小空胞けは掋大した粗面小胞体尧である。 $\times 15,000$ 


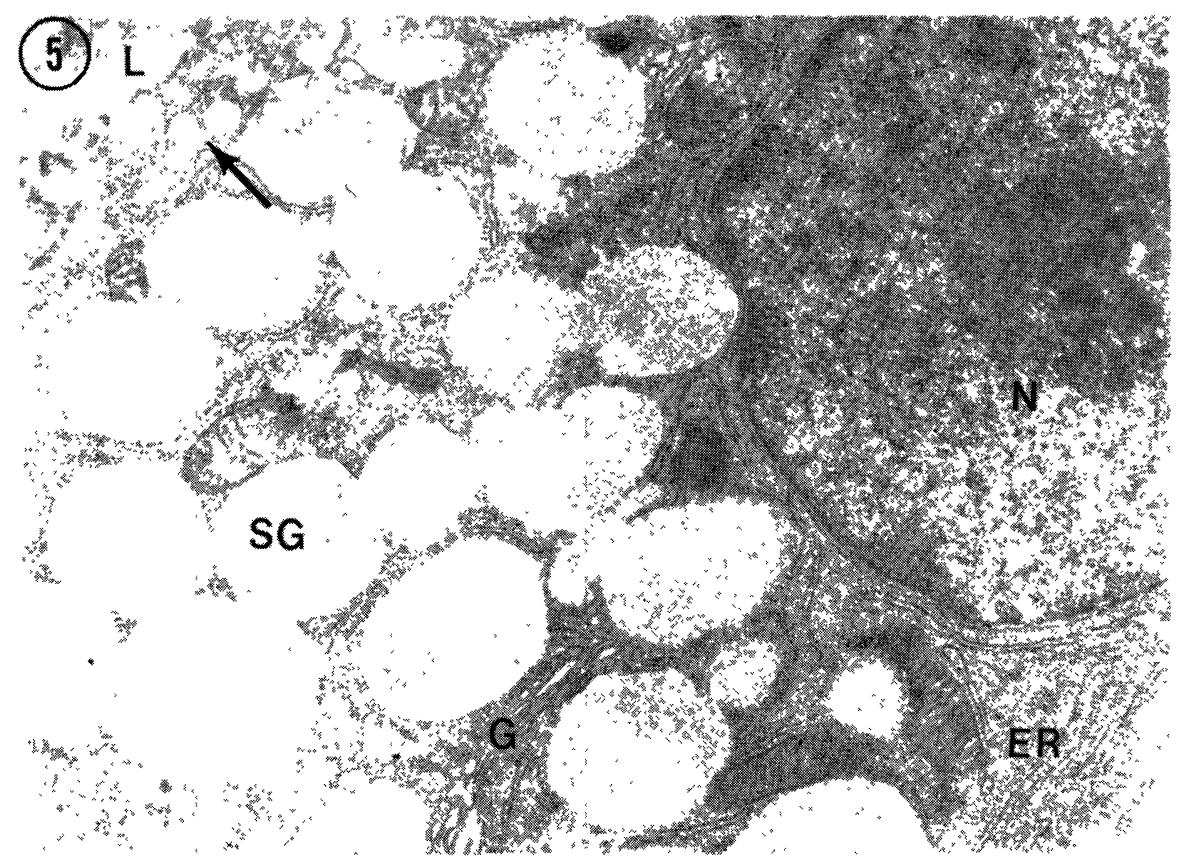

図 5.下垂体蕉分断夫の cinchophen 投与後胃腺主細胞。

分泌顆粒 $(\mathrm{S} G)$ は核上部から細胞先端部にまで允満するが、排出像はほとんどみられない。Golgi 装置(G)では層板の搪 大はほとんどみられず，分泌顆粒形成像は極めて弱い。粗面小胞体 (ER) 法減少し配列は疎である。細胞先端部にはか

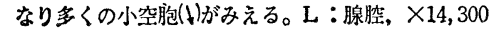

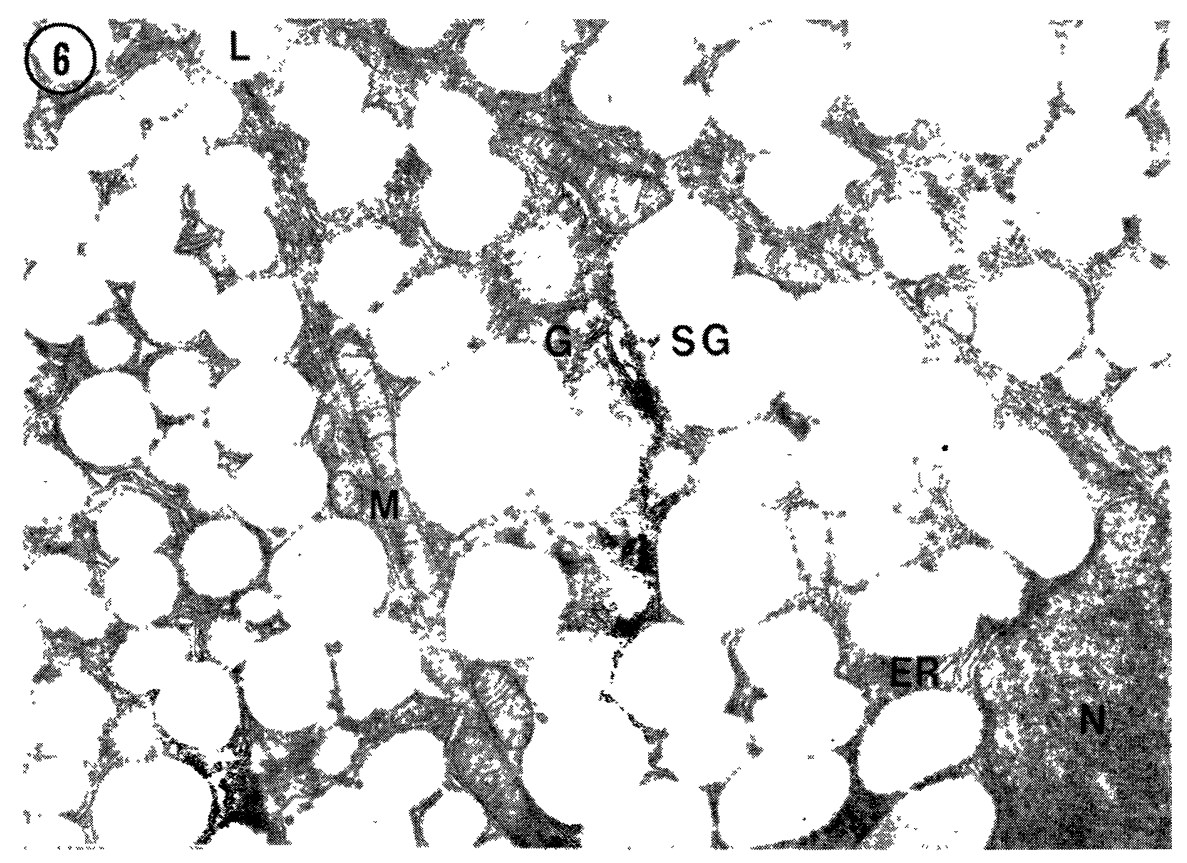

図 6. 迷走神経切断夫の飢餓時胃腺主細胞。

稩胞内には分泌顆粒 $(\mathrm{S} \mathrm{G})$ が充満し、核側部から基底部にまでおよんでいる。Golgi 装置(G)における分泌顆粒形成像 は少い。粗面小胞体 (ER) は比較的少なく首板状に配列している。 X5,200 
(102)

牛尾

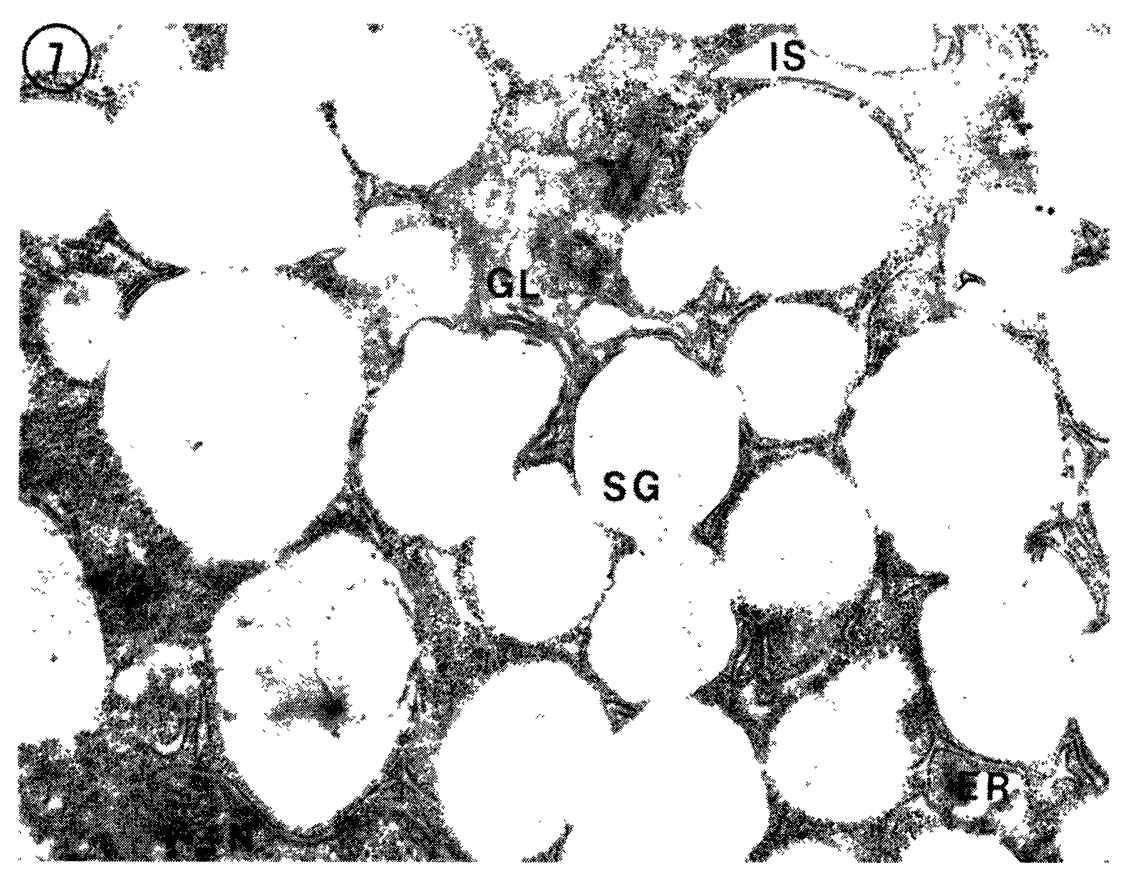

图7. 迷走神経切断犬の cinchophen 投与後胃腺主細胞。

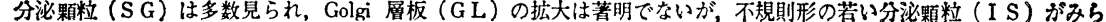
沉る。粗面小胞体 (ER) は扁平襄状で分泌顆粒間にるられる。 X14,300

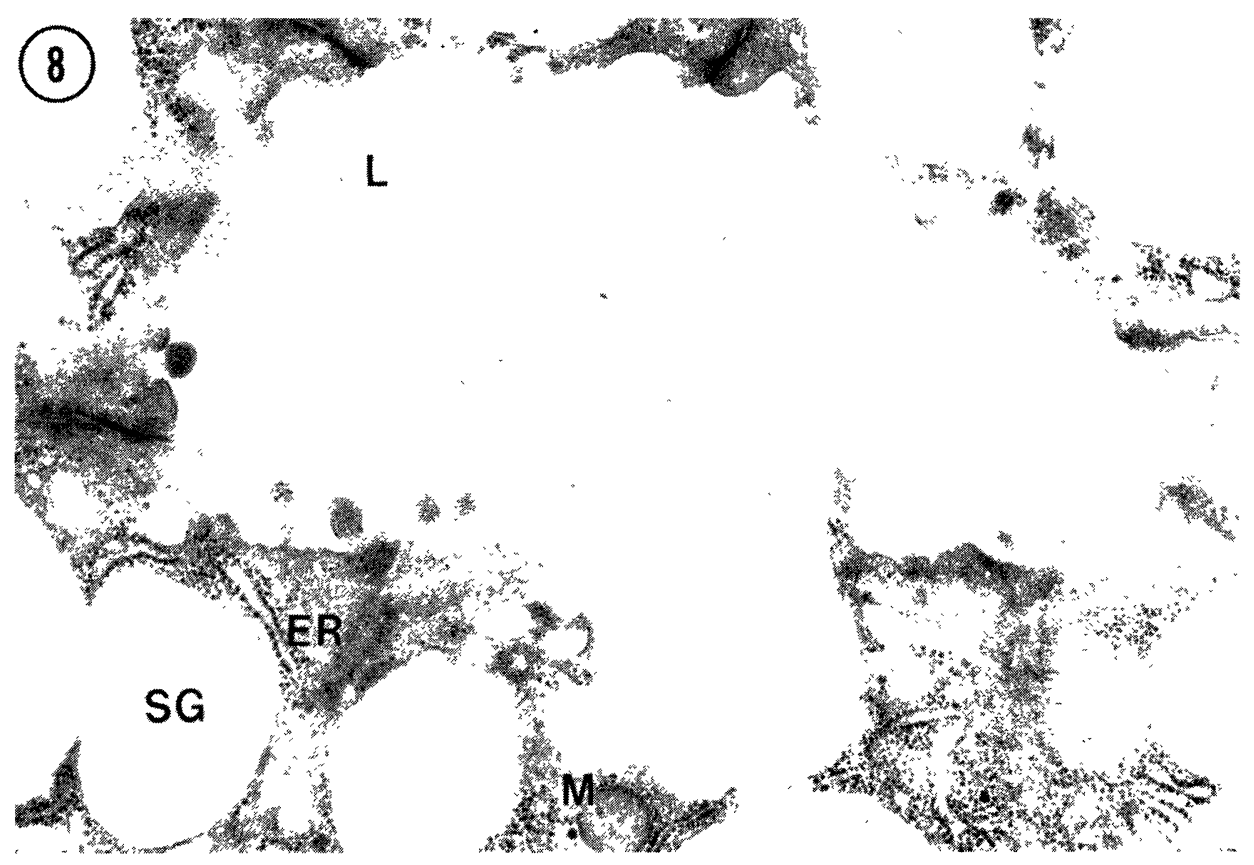

图 8. 迷走神経切断犬のcinchophen 投与後胃腺主細胞。

湶㭙(L)に分泌顆粒（S G) のmicroapocrine 機序による排出像がみられる。 $\times 21,900$ 


\section{ELEGTRON MIGROSCOPIC STUDIES OF CANINE GASTRIC GHIEF GELLS ON PEPSIN SECRETION INDUCED BY CINCHOPHEN AKIRA USHIO

\author{
Department of Surgery I, Gunma University, \\ School of Medicine, Maebashi, Japan \\ (Director : Prof. Keizo Ishihara)
}

Electron microscopic changes in the chief cell of the canine gastric gland after cinchophen administion were investigated, as compared with those after insulin administration.

The chief cells in the normal dog in response to cinchophen decreased in secretory granules, showing a picture of increasing excretion on the luminal surface. The Golgi cisternae were enlarged. indicating a marked production of secretory granules, and rough-surfaced endoplasmic reticula showed parallel disposition in contrast with distorted irregular arrangement seen after insulin administration.

In stalk-sectioned dogs, cinchophen in contrast with insulin failed to accelerate the secretion of the gastric chief cells: There were many secretory granules, their excretion was hardly discernible in the lumen of the cells, and the Golgi cisternae were scarcely enlarged, indicating very poor production of secretory granles, and rough-surfaced endoplasmic reticula were arranged in parallal and dispersed disposition.

In vagotomized dogs, secretory granules were found numerously after cinchophen administraion, and their excretion was demonstrated to a considerable degree, whereas it was scarce after insulin administration. Enlargement of the Golgi cisternae and production of secretory granules were not remarkable, and rough-surfaced endoplasmic reticula showed a parallel disposition.

It is considered from these findings that cinchophen accelerates the secretion of the gastric chief cells, and that the acceleration is inhibited strongly by pituitary stalk section and also to a lesser degree by vagotomy. 